Louisiana State University LSU Digital Commons

1991

\title{
Response of determinate soybean cultivars to low pH soils.
}

JE. Board

Follow this and additional works at: http://digitalcommons.lsu.edu/agexp

\section{Recommended Citation}

Board, J E., "Response of determinate soybean cultivars to low pH soils." (1991). LSU Agricultural Experiment Station Reports. 349. http://digitalcommons.lsu.edu/agexp/349

This Article is brought to you for free and open access by the LSU AgCenter at LSU Digital Commons. It has been accepted for inclusion in LSU Agricultural Experiment Station Reports by an authorized administrator of LSU Digital Commons. For more information, please contact gcoste1@lsu.edu. 


\section{Response of \\ Determinate Soybean Cultivars to Low pH Soils}

\section{J. E. Board and A. G. Caldwell}
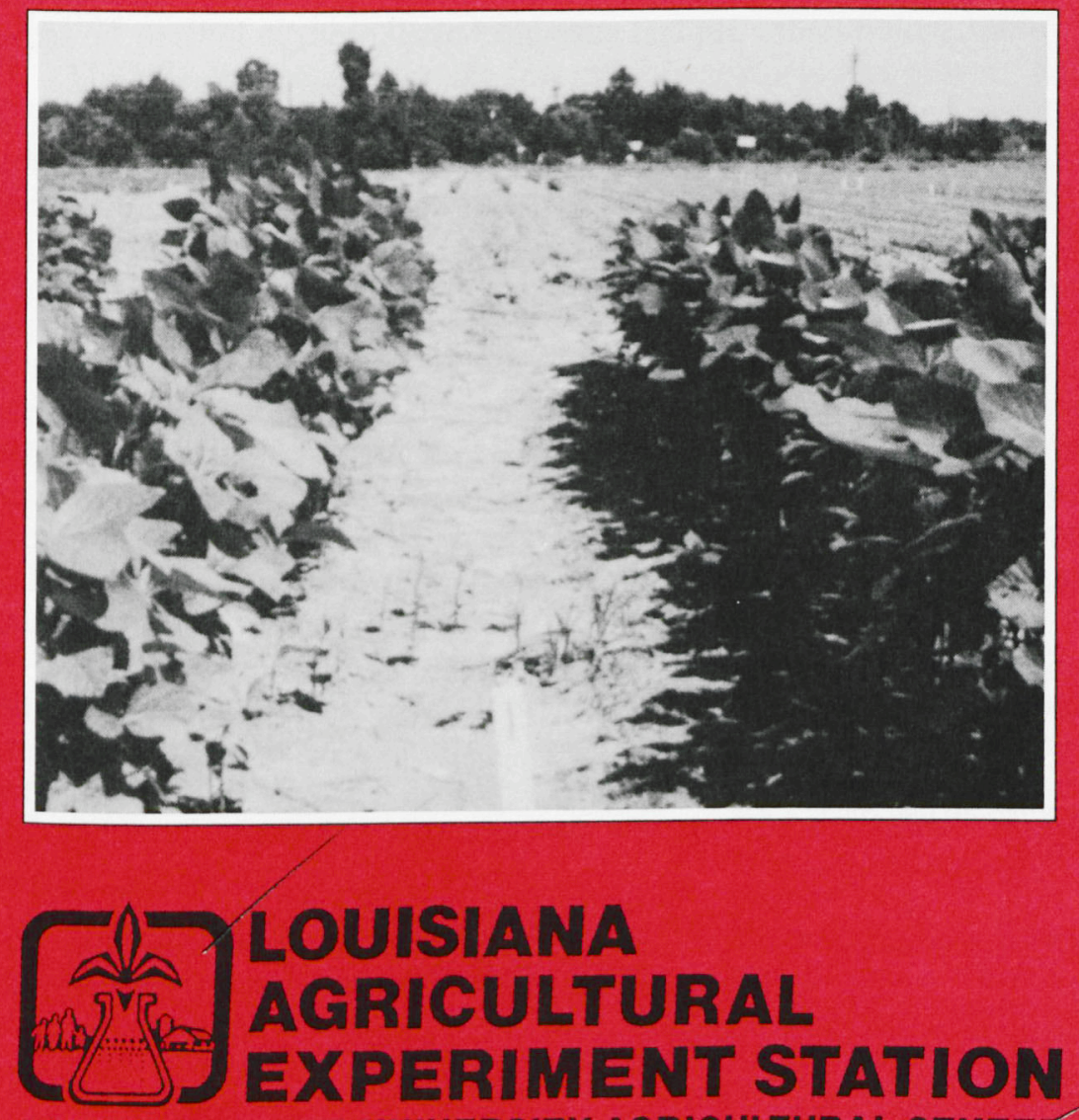
LOUISIANA STATE UNIVERSITY AGRICULTURAL CENTEK 


\section{Contents}

Introduction

Page

Materials and Methods

Results and Discussion

Summary

References

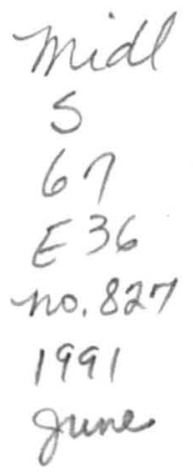

Louisiana Agricultural Experiment Station, Kenneth W. Tipton, Director Louisiana State University Agricultural Center, H. Rouse Caffey, Chancellor

The Louisiana Agricultural Experiment Station follows a nondiscriminatory policy in programs and employment. 


\section{Response of Determinate Soybean Cultivars to Low pH Soils}

J. E. BOARD AND A. G. CALDWELL ${ }^{1}$

\section{Introduction}

Soybean production in Louisiana and throughout the southeastern United States is adversely affected by low-pH soils. Acid soils can reduce plant growth and yield by increasing the soil concentration of hydrogen, aluminum, and manganese to toxic levels; decreasing the availability of calcium, magnesium, and molybdenuum; and adversely affecting rhizobium nodulation and nitrogen $\left(\mathrm{N}_{2}\right)$ fixation (Mengel et al., 1987). Based on studies from several soil types of the southeastern United States, soybean has demonstrated a critical soil $\mathrm{pH}$ in the range of 5.2-5.4. Sedberry et al. (1973) reported that with the exception of the floodplains of the Mississippi and Red rivers, 35 percent of the soils in Louisiana had $\mathrm{pH}$ values below 5.5.

The high [hydrogen] assocth low $\mathrm{pH}$ soils restricts root growth, which may reduce nutrient uptake and growth (Mengel et al., 1987). However, direct root injury by high [hydrogen] occurs only if soil $\mathrm{pH}$ falls below 4 . Aluminum toxicity has been reported to be the most important factor affecting yield on acid soils (Mengel et al., 1987). Toxicity generally occurs when soil $\mathrm{pH}$ falls below 5.5 and results in short stubby roots with reduced capability for water and nutrient absorption (Mengel et al., 1987). Accumulation of toxic amounts of aluminum by soybeans in acid soils and cultivar variation in aluminum tolerance have been reported (Blair and Prince, 1923; McLean and Gilbert, 1927; McLean and Gilbert, 1928). In more recent studies, Foy (1974) reported that resistant cultivars had less root aluminum accumulation in the roots. Sartain (1974) demonstrated an association between cultivar resistance to yield losses induced by aluminum, and the ability to accumulate more calcium, magnesium, and phosphorus.

The second most important factor in affecting growth and yield on acid soils is manganese toxicity (Mengel et al., 1987). Manganese toxicity also generally occurs when soil pH falls below 5.5 (Foy, 1984). The main symptom of manganese toxicity is terminal leaf chlorosis accompanied by leaf crinkling. Diagnosis can be accomplished by leaf concentration analysis.

'Associate Professor and Professor, respectively, Department of Agronomy, Louisiana Agricultural Experiment Station, LSU Agricultural Center, Baton Rouge, La. 70803. 
A toxicity range of $300-500 \mathrm{mg} \mathrm{kg}^{1}$ has been reported (Adams, 1984). However, lower toxicity ranges $\left(160 \mathrm{mg} \mathrm{kg}^{1}\right)$ have also been shown (Ohki, 1976). Variation in reports of the critical manganese level for toxicity may be due to differences in plant age, growth stage, plant part, cultivars, and growing season (Anderson and Mortvedt, 1982). Toxic levels of manganese in leaf tissue adversely affect growth and yield by disrupting enzyme reactions (Helyar, 1978), and reducing the uptake and/or transport of other nutrients such as calcium and iron (Mengel et al., 1987). Differential cultivar responses to high levels of leaf manganese have been reported (Carter et al., 1975; Heenan and Carter, 1976; Ohki et al., 1980; Caldwell et al., 1984).

Low Soil $\mathrm{pH}$ can also have an adverse effect on nitrogen $\left(\mathrm{N}_{2}\right)$ fixation, the primary method by which soybeans obtain nitrogen. Early studies reported reduced nodulation when $\mathrm{pH}$ fell below 4.6(Doolas, 1930). Mengel and Kamprath (1978) reported that increasing $\mathrm{pH}$ from 4.6 to 4.8 resulted in greater nodule number and weight, and higher nitrogen uptake rates. Acid soils with a pH below 5.5 have also been shown to reduce the availability of molybdenum, an element required in nitrogen $\left(\mathrm{N}_{2}\right)$ fixation (Sedberry et al., 1973). The availability of molybdenum is also affected by molybdenum and iron soil content (Lucas and Knezek, 1971).

Information on cultivar response to acid soil among determinate cultivars is lacking. Since soil acidity is a major problem in the agriculture of Louisiana and much of the southeastern United States, the objectives of this study were to determine yield responses of several determinate cultivars between limed and low-pH soil, to determine which cultivars perform best on low-pH soils, and to determine what changes in plant and soil mineral concentrations were associated with these yield responses.

\section{Materials and Methods}

Culture. Field studies were conducted in 1984, 1985, and 1986 at the Burden Research Plantation, Baton Rouge, LA (30 N Lat.) on an Olivier silt loam (fine-silty, mixed, thermic, Typic Fragiudalf) soil. Fertilizer was applied prior to planting at a rate of $0-72-72$ pounds $\mathrm{A}^{-1}(\mathrm{~N}-\mathrm{P}-\mathrm{K})$. Recommended practices were used for weed, disease, and insect control. The test was machine-planted on June 13, May 21, and May 7 in 1984, 1985, and 1986 , respectively, at the rate of 12 seed ft $^{-1}$ of row in 3-row plots having 40inch row width. Liming was achieved in high $\mathrm{pH}$ plots by incorporating 2000 pounds $\mathrm{A}^{-1}$ of agricultural lime. In order to compensate for variable soil $\mathrm{pH}$, different amounts of alum $\left[\mathrm{Al}_{2}\left(\mathrm{SO}_{4}\right)_{3} \cdot 18 \mathrm{H}_{2} \mathrm{O}\right](8$ percent aluminum, 14 percent sulfur) were applied to create the low-pH treatments. One ton $\mathrm{A}^{-1}$ was incorporated into replications 1 and 2 . Two tons $\mathrm{A}^{-1}$ were incorporated into replications 3 and 4 . Subsoil treatments were applied in the furrow created by a moldboard plow, rototilled, and covered. Surface treatments were disked into the topsoil. Lime and alum applications were made in late April, 1984. The soil was allowed to equiliberate eight weeks before planting 
in order to achieve uniform $\mathrm{pH}$ within the limed and low-pH portions of the field.

Data Collected. Seed yield, adjusted to 13 percent moisture, was measured on the interior row of each plot after end-trimming to 14 feet. Plant height, maturity date, low pod height, lodging, and seed quality were recorded for each plot. Leaf samples for tissue analyses were obtained in each year of the study at the R5 state (Fehr and Caviness, 1977) by selecting 45 of the most recently fully-expanded trifoliate leaves from the center row of each plot. Leaf mineral concentrations of calcium, magnesium, phosphorus, sulfur, iron, manganese, iron, and zinc were obtained by wet digestion according to the method of Havlin and Soltanpour (1981) as described by Cherney and Robinson (1983). Analysis was conducted by an ARL Inductively Coupled Plasma Emission Spectrometer. Plant nitrogen uptake was determined in each year by harvesting one foot of row from each plot at the R6 stage (Fehr and Caviness, 1977). Total nitrogen was determined by the Kjeldahl method.

Soil samples at depths of 0-6 inches, 6-12 inches, 12-18 inches, and 1824 inches were collected from each plot in the fall of 1985 and 1986. Unfortunately, soil samples taken in 1984 were mislabeled in a laboratory mistake. Analyses were conducted for $\mathrm{pH}$, [potassium], [phosphorus], [calcium], [magnesium], [zinc], and [aluminum] based on samples taken from the top six inches of soil. Soil $\mathrm{pH}$ was determined in a 1:1 water mixture (McLean, 1982). Phosphorus was extracted in a strong acid Bray solution (Burnside and Sturgis, 1958). Potassium, calcium, and magnesium extraction was done in a $\mathrm{M}$ ammonium acetate solution at $\mathrm{pH} 7$ (Thomas, 1982). Aluminum was extracted in a $1 \mathrm{M} \mathrm{KCl}$ solution (Barnhisel and Bertsch, 1982). Soil manganese and zinc were extracted by the DTPA test (Lindsay and Norvell, 1978). Concentrations of all extracted minerals were then determined in an ARL Inductively Coupled Plasma Emission Spectrometer.

Experimental Design and Data Analysis. The experimental design was a split-split plot with four replications. Main plots were the three years of the study: 1984, 1985, and 1986. Split plots were limed, and low-pH treatments described under cultural methods. Although slight variation occurred between plots, average $\mathrm{pH}$ in the limed and low-pH treatments were 6.4 and 5.2, respectively. Split-split plots were 13 commercial soybean cultivars: Maturity Group V entries 'Forrest', 'Deltapine 345', and 'Wilstar 550'; Maturity Group VI entries 'Ring Around 680', 'Davis', and 'Pickett 71'; Maturity Group VII entries 'Hartz 71-26', 'Terra Vig 708', and 'Bragg'; and Maturity Group VIII entry 'Coker 348'.

All data were analyzed by analysis of varifance (anovar). Year effect was tested for significance using replication $\mathrm{x}$ year interaction as the error term $\left(\mathrm{E}_{\mathrm{a}}\right)$. Lime and lime $\mathrm{x}$ cultivar interaction were treated for significance using the replication $\mathrm{x}$ lime (year) interaction as the error term $\left(\mathrm{E}_{\mathrm{b}}\right)$. All other 
factors were tested for significance using error mean square $\left(E_{c}\right)$. Mean separation was done with the least significant difference (LSD) $(\mathrm{p}=0.05)$ test. Weighted standard errors and $t$ values were calculated for specific mean comparisons using appropriate combinations of $\mathrm{E}_{\mathrm{a}}, \mathrm{E}_{\mathrm{b}}, \mathrm{E}_{\mathrm{c}}$, and $\mathrm{t}_{\mathrm{a}}, \mathrm{t}_{\mathrm{b}}, \mathrm{t}_{\mathrm{c}}$. Correlation analysis was done with a SAS program using Proc Corr.

\section{Results and Discussion}

Soil Responses to Liming and Acidification. Application of aluminum sulfate resulted in soil conditions comparable to what would be expected in an acid Louisiana soil in which acidity was induced by leaching of soluble bases. Soil $\mathrm{pH}$ was reduced to a level similar to that in a naturally acid soil (Table 2). Soil aluminum and manganese were increased to concentrations similar to those found in acid Louisiana soils (tables 3 and 4 , respectively).

Liming had a highly significant effect on soil $\mathrm{pH}$ (Table 1). In every cultivar (Table 2), soil $\mathrm{pH}$ was higher in limed as compared to low-pH plots. Overall, liming increased the $\mathrm{pH}$ of the soil from a mena of 5.2 to 6.4. Significant year $\mathrm{x}$ lime and year $\mathrm{x}$ cultivar interactions indicated that the liming effect on $\mathrm{pH}$ was not consistent across years or cultivars (Table 1). Although pH in limed soil did not increase between 1985 to 1986 (6.4), there was a substantial rise in $\mathrm{pH}$ in the low-pH plots from 4.9 to 5.4 between 1985 to 1986.

It appears that the effect of the original soil acidity treatments in 1984 gradually declined over the years of the study. Significant lime x cultivar interaction indicated the $\mathrm{pH}$ changes between limed and low-pH plots were larger in some cultivars as compared to others. This can be attributed to chance soil variability, rather than a cultivar effect on soil $\mathrm{pH}$. In the limed plots, Pickett 71 and Lee 74 had pH levels significantly higher than average. In the low-pH plots, Deltapine 345 and Coker 156 had pH higher than average, while Bragg was below average. In spite of both year and cultivar interactions with liming treatments in this study, $\mathrm{pH}$ levels in the low-pH plots for all cultivars were below the 5.5 critical level at which adverse effects on growth and yield can be expected.

Liming had no significant effect on phosphorus and potassium soil levels (Table 1). Levels of both macronutrients were well above adequate concentration in both limed and low-pH treatments (Table 3). Liming did have a significant effect on calcium and magnesium soil concentrations (Table 1). Concentrations of these two elements were generally lower in low-pH as compared to limed plots (Table 3). However, values for all cultivars in both limed and low-pH soil were within the adequate range for soybeans. Thus liming effects on calcium, magnesium, phosphorus, and potassium soil concentrations were not large enough to affect plant growth and yield. 
Table 1.-Anovar for soil pH and soil concentrations fo $\mathrm{Ca}, \mathrm{Mg}, \mathrm{P}, \mathrm{K}$, and $\mathrm{Mn}$ in limed and low pH soil at Baton Rouge, LA, 1985 and 1986

\begin{tabular}{|c|c|c|c|c|c|c|c|c|c|c|c|c|c|}
\hline \multirow[b]{2}{*}{ Source of Variation } & \multirow[b]{2}{*}{ DF } & \multicolumn{2}{|c|}{$\mathrm{pH}$} & \multicolumn{2}{|c|}{$\mathrm{Ca}$} & \multicolumn{2}{|c|}{$\mathrm{Mg}$} & \multicolumn{2}{|c|}{$\mathrm{P}$} & \multicolumn{2}{|c|}{$\mathrm{K}$} & \multicolumn{2}{|c|}{$M n$} \\
\hline & & $\begin{array}{l}\text { Mean } \\
\text { square }\end{array}$ & $\begin{array}{l}\text { Signifi- } \\
\text { cance } \\
\text { level }\end{array}$ & $\begin{array}{l}\text { Mean } \\
\text { square }\end{array}$ & $\begin{array}{l}\text { Signifi- } \\
\text { cance } \\
\text { level }\end{array}$ & $\begin{array}{l}\text { Mean } \\
\text { square }\end{array}$ & $\begin{array}{l}\text { Signifi- } \\
\text { cance } \\
\text { level }\end{array}$ & $\begin{array}{l}\text { Mean } \\
\text { square }\end{array}$ & $\begin{array}{l}\text { Signifi- } \\
\text { cance } \\
\text { level }\end{array}$ & $\begin{array}{l}\text { Mean } \\
\text { square }\end{array}$ & $\begin{array}{l}\text { Signifi- } \\
\text { cance } \\
\text { level }\end{array}$ & $\begin{array}{l}\text { Mean } \\
\text { square }\end{array}$ & $\begin{array}{l}\text { Signifi- } \\
\text { cance } \\
\text { level }\end{array}$ \\
\hline Year & 1 & 3.20 & .02 & 90,516 & .14 & 20,109 & .10 & 100 & .43 & 5,059 & .11 & 10,089 & .001 \\
\hline Lime & 1 & 82.00 & .0001 & $7,561,504$ & .002 & 23,833 & .03 & 84 & .41 & 381 & .67 & 136,641 & .0001 \\
\hline Cultivar & 12 & .20 & .001 & 83,296 & .01 & 1,180 & .10 & 23 & .88 & 287 & .37 & 602 & .0001 \\
\hline Year $\times$ Lime & 1 & 2.20 & .007 & 12,843 & .83 & 6 & .96 & 11 & .76 & 67 & .86 & 15,066 & .0003 \\
\hline Year $\times$ Cultivar & 12 & .03 & .90 & 3,858 & 1.00 & 125 & 1.00 & 48 & .31 & 123 & .93 & 61 & .98 \\
\hline Lime $\times$ Cultivar & 12 & .14 & .002 & 98,466 & .003 & 1,942 & .003 & 53 & .23 & 319 & .27 & 425 & .005 \\
\hline Year $\times$ Lime $\times$ Culfivar & 12 & .03 & .88 & 5,542 & 1.00 & 346 & .93 & 39 & .49 & 197 & .70 & 44 & .99 \\
\hline Error (a) & & .18 & & 20,990 & & 3,764 & & 118 & & 968 & & 59 & \\
\hline Error (b) & & .14 & & 246,195 & & 2,850 & & 106 & & 1,953 & & 274 & \\
\hline Error (c) & & .0526 & & 37,529 & & 734 & & 41 & & 262 & & 170 & \\
\hline CV (\%) & & 4.0 & & 14.2 & & 14.1 & & 23.7 & & 18.6 & & 17.2 & \\
\hline
\end{tabular}


Table 2.-Soil $\mathrm{pH}$ as affected by liming treatment, year, and cultivar, Baton Rouge, LA, 1985 and 1986

\begin{tabular}{|c|c|c|c|c|c|c|}
\hline \multirow[b]{2}{*}{ Cultivar } & \multicolumn{2}{|c|}{1985} & \multicolumn{2}{|c|}{1986} & \multicolumn{2}{|c|}{ Mean } \\
\hline & Limed & Low-pH & Limed & Low-pH & Limed & Low-pH \\
\hline \multicolumn{7}{|l|}{ Maturity Group V } \\
\hline Forrest & 6.4 & 5.0 & 6.2 & 5.3 & 6.3 & 5.1 \\
\hline Deltapine 345 & 6.5 & 5.2 & 6.3 & 5.6 & 6.4 & 5.4 \\
\hline Wilstar 550 & 6.5 & 5.2 & 6.4 & 5.8 & 6.4 & 5.5 \\
\hline \multicolumn{7}{|l|}{ Maturity Group VI } \\
\hline Ring Around 680 & 6.5 & 4.9 & 6.5 & 5.4 & 6.5 & 5.1 \\
\hline Lee 74 & 6.5 & 5.0 & 6.6 & 5.3 & 6.6 & 5.1 \\
\hline Centennial & 6.4 & 4.9 & 6.6 & 5.3 & 6.5 & 5.1 \\
\hline Coker 156 & 6.4 & 5.2 & 6.5 & 5.6 & 6.4 & 5.4 \\
\hline Davis & 6.5 & 5.0 & 6.6 & 5.4 & 6.5 & 5.2 \\
\hline Pickett 71 & 6.5 & 4.9 & 6.7 & 5.4 & 6.6 & 5.1 \\
\hline \multicolumn{7}{|l|}{ Maturity Group VII } \\
\hline Hartz 71-26 & 6.4 & 4.8 & 6.5 & 5.4 & 6.4 & 5.1 \\
\hline Terra Vig 708 & 6.3 & 5.0 & 6.4 & 5.4 & 6.3 & 5.2 \\
\hline Bragg & 6.3 & 4.6 & 6.4 & 5.1 & 6.4 & 4.8 \\
\hline \multicolumn{7}{|l|}{ Maturity Group VIII } \\
\hline Coker 368 & 6.3 & 4.8 & 6.2 & 5.5 & 6.3 & 5.1 \\
\hline Mean & 6.4 & 4.9 & 6.4 & 5.4 & 6.4 & 5.2 \\
\hline \multicolumn{4}{|c|}{$\begin{array}{l}\text { LSD }\left({ }_{05}\right) \text { for comparing the same cultivar } \\
\text { between limed and low-pH treatments within the } \\
\text { same year }\end{array}$} & .25 & & \\
\hline \multicolumn{4}{|c|}{$\begin{array}{l}\left.\text { LSD ( }{ }^{\circ}\right) \text { for comparing different cultivar means } \\
\text { within a limed or low-pH treatment within the } \\
\text { same year }\end{array}$} & .23 & & \\
\hline
\end{tabular}

Absence of any detectable aluminum in soil samples from the limed soil precluded an analysis of variance of soil aluminum. Aluminum concentrations in low-pH plots (Table 3) were not great enough to affect plant growth and yield since they represented only a 5-15 percent aluminum saturation of the cation exchange capacity. Evans and Kamprath (1970) reported that aluminum becomes toxic to soybeans when it occupies 30 percent of the exchange sites. This usually does not occur until soil $\mathrm{pH}$ falls below 5.0. Thus in this study, aluminum concentration in low-pH plots did not have an adverse effect on growth and yield.

Liming treatments strongly affected the concentrations of soil manganese (Table 1). Significant year and cultivar interactions with liming treatment on soil [manganese] also occurred. The significant cultivar $\mathrm{x}$ lime interaction was not due to a cultivar effect on [manganese], but rather was caused by soil variability. In 1985, manganese concentrations were at least twice as high in low-pH versus limed plots. The same trend persisted in 1986, except the differences were not quite as great. 
Thus the biggest effects of liming treatments on soil mineral concentrations in this study were on manganese. However, soil concentrations of manganese are not completely reliable in predicting manganese toxicity in soybeans because some soils lack adequate manganese to produce toxicity under any pH level (Adams, 1984). Soil organic matter content, CEC, and redox potential also will affect manganese availability to soybeans (Mengel, et al., 1987).

Response of Seed Yield to Liming. The analysis of variance (Table 5) showed that lime treatments in this study had a highly significant impact on reducing seed yield. Although year also had a significant influence on seed yield, year $\mathrm{x}$ lime interaction was insignificant, indicating that the influence on lime on seed yield was consistent across years. Thus the increase in soil pH between 1985 and 1986 in the low-pH treatments (Table 2 ) was not large enough to ameliorate the yield reductions caused by the acid soils. The highly significant lime $\mathrm{x}$ cultivar interaction made it necessary to study individual cultivar means in limed and low-pH treatments. Since lime had a consistent effect on seed yield across years and there was no significant year $\mathrm{x}$ lime $\mathrm{x}$ cultivar interaction (Table 5), cultivar seed yields within limed and low-pH treatments were averaged over the three years of the study.

Seed yields were depressed by soil acid conditions much more in some cultivars as compared to others (Table 6). Across all cultivars, the seed yield decline due to soil acidity was 25 percent. Seed yield was significantly higher in limed versus low-pH treatments in all cultivars except Deltapine 345 and Terra Vig 708. Cultivar variation in lime response is manifested in the percent seed yield decline due to acid soil conditions (Table 6). Percentages varied from a low as 7.6 in Terra Vig 708 to as high as 49.7 in Bragg. Forrest, Ring Around 680, and Hartz 71-26 had seed yield declines due to soil acidity of only 15-18 percent, while Coker 368, Pickett 71, Coker 156, and Centennial had approximately 25 percent average seed yield reductions. Lee 74 and Wilstar 550 had seed yield reductions of 35.8 and 36.4 percent, respectively, due to low-pH soil.

Based on differences in cultivar resonse to soil acidity, Terra Vig 708 and Deltapine 345 were classified as very insensitive to soil acidity; Forrest, Ring Around 680 and Hartz 71-26 were moderately insensitive; Coker 368, Pickett 71, Coker 156, and Centennial were sensitive cultivars; Lee 74 and Wilstar 550 were very sensitive; and Davis and Bragg were severely sensitive. No relationship existed between cultivar sensitivity to soil acidity and variation in soil $\mathrm{pH}$ (Table 2) in the low-pH treatments. Wilstar 550 is very sensitive to soil acidity, while having the highest $\mathrm{pH}(5.5$, Table 2$)$ of any cultivar on the unlimed plots. Terra Vig 708 was very insensitive to soil acidity, while having a $\mathrm{pH}$ of 5.2 - the average value for cultivars in low-pH plots. Thus the cultivar responses to soil acidity in this study represent true genetic responses and are not due to the moderate variation in soil $\mathrm{pH}$ between cultivars on the low-pH plots. 
Table 3.-Effect of liming on soil extractable Ca, Mg, P, K, and Al averaged over two years at Baton Rouge, LA, 1985-86

\begin{tabular}{|c|c|c|c|c|c|c|c|c|c|c|}
\hline \multirow[b]{2}{*}{ Cultivar } & \multicolumn{2}{|c|}{ Ca (ppm) } & \multicolumn{2}{|c|}{$M g(p p m)$} & \multicolumn{2}{|c|}{$P(p p m)$} & \multicolumn{2}{|c|}{$\mathrm{K}(\mathrm{ppm})$} & \multicolumn{2}{|c|}{$\mathrm{Al}(\operatorname{meg} 100 \mathrm{~g}-1)$} \\
\hline & Limed & Unlimed & Limed & Unlimed & Limed & Unlimed & Limed & Unlimed & Limed & Unlimed \\
\hline \multicolumn{11}{|l|}{ Maturity Group V } \\
\hline $\begin{array}{l}\text { Forrest } \\
\text { Deltapine } 345 \\
\text { Wilstar } 550\end{array}$ & $\begin{array}{l}1548 \\
1582 \\
1600\end{array}$ & $\begin{array}{l}1087 \\
1339 \\
1401\end{array}$ & $\begin{array}{l}218 \\
205 \\
207\end{array}$ & $\begin{array}{l}179 \\
194 \\
206\end{array}$ & $\begin{array}{l}25 \\
28 \\
26\end{array}$ & $\begin{array}{l}32 \\
27 \\
31\end{array}$ & $\begin{array}{l}89 \\
82 \\
83\end{array}$ & $\begin{array}{r}90 \\
92 \\
104\end{array}$ & $\begin{array}{l}0.0 \\
0.0 \\
0.0\end{array}$ & $\begin{array}{l}0.4 \\
0.2 \\
0.1\end{array}$ \\
\hline $\begin{array}{l}\text { Maturity Group IV } \\
\text { Ring Around } 680 \\
\text { Lee } 74 \\
\text { Centennial } \\
\text { Coker } 156 \\
\text { Davis } \\
\text { Pickett } 71\end{array}$ & $\begin{array}{l}1571 \\
1603 \\
1477 \\
1430 \\
1557 \\
1577\end{array}$ & $\begin{array}{l}1220 \\
1135 \\
1224 \\
1354 \\
1111 \\
1138\end{array}$ & $\begin{array}{l}198 \\
188 \\
199 \\
190 \\
190 \\
195\end{array}$ & $\begin{array}{l}190 \\
182 \\
190 \\
201 \\
173 \\
175\end{array}$ & $\begin{array}{l}24 \\
25 \\
25 \\
29 \\
29 \\
26\end{array}$ & $\begin{array}{l}25 \\
27 \\
30 \\
28 \\
27 \\
26\end{array}$ & $\begin{array}{l}81 \\
85 \\
82 \\
89 \\
79 \\
77\end{array}$ & $\begin{array}{l}89 \\
94 \\
90 \\
87 \\
79 \\
84\end{array}$ & $\begin{array}{l}0.0 \\
0.0 \\
0.0 \\
0.0 \\
0.0 \\
0.0\end{array}$ & $\begin{array}{l}0.2 \\
0.3 \\
0.4 \\
0.2 \\
0.4 \\
0.4\end{array}$ \\
\hline $\begin{array}{l}\text { Maturity Group VII } \\
\text { Hartz } 71-26 \\
\text { Terra Vig } 708 \\
\text { Bragg }\end{array}$ & $\begin{array}{l}1649 \\
1458 \\
1544\end{array}$ & $\begin{array}{r}1108 \\
1100 \\
878\end{array}$ & $\begin{array}{l}215 \\
194 \\
208\end{array}$ & $\begin{array}{l}178 \\
168 \\
151\end{array}$ & $\begin{array}{l}26 \\
25 \\
30\end{array}$ & $\begin{array}{l}28 \\
26 \\
24\end{array}$ & $\begin{array}{l}97 \\
92 \\
95\end{array}$ & $\begin{array}{l}88 \\
93 \\
84\end{array}$ & $\begin{array}{l}0.0 \\
0.0 \\
0.0\end{array}$ & $\begin{array}{l}0.2 \\
0.2 \\
0.6\end{array}$ \\
\hline $\begin{array}{l}\text { Maturity Group VIII } \\
\text { Coker } 368\end{array}$ & 1562 & 1109 & 231 & 168 & 23 & 30 & 92 & 84 & 0.0 & 0.3 \\
\hline Mean & 1552 & 1169 & 203 & 181 & 26 & 28 & 86 & 88 & 0.0 & 0.3 \\
\hline $\begin{array}{l}\text { LSD }\left({ }_{05}\right) \text { for comparing the } \\
\text { same cultivar between limed and } \\
\text { low-pH treatments }\end{array}$ & & 175 & & 22 & & $\mathrm{NS}^{\mathrm{a}}$ & & NS & & NS \\
\hline
\end{tabular}


LSD $\left({ }_{05}\right)$ for comparing

different cultivar means within

a limed or low-pH treatment

aN = not significant. 
Table 4.- Mn concentration in limed and low-pH soil at Baton Rouge, LA, 1985 and 1986

\begin{tabular}{|c|c|c|c|c|c|c|}
\hline \multirow[b]{2}{*}{ Cultivar } & \multicolumn{2}{|c|}{1985 (ppm) } & \multicolumn{2}{|c|}{1986 (ppm) } & \multicolumn{2}{|c|}{ Mean (ppm) } \\
\hline & Limed & Low-pH & Limed & Low-pH & Limed & Low-pH \\
\hline \multicolumn{7}{|l|}{ Maturity Group V } \\
\hline Forrest & 50 & 119 & 53 & 88 & 52 & 103 \\
\hline Deltapine 345 & 41 & 107 & 48 & 80 & 44 & 93 \\
\hline Wilstar 550 & 42 & 101 & 49 & 76 & 45 & 89 \\
\hline \multicolumn{7}{|l|}{ Maturity Group VI } \\
\hline Ring Around 680 & 43 & 121 & 50 & 84 & 47 & 102 \\
\hline Lee 74 & 51 & 118 & 50 & 84 & 51 & 101 \\
\hline Centennial & 51 & 117 & 52 & 79 & 51 & 98 \\
\hline Coker 156 & 52 & 98 & 57 & 77 & 54 & 88 \\
\hline Davis & 46 & 112 & 47 & 91 & 47 & 102 \\
\hline Pickett 71 & 42 & 124 & 45 & 88 & 43 & 106 \\
\hline \multicolumn{7}{|l|}{ Maturity Group VII } \\
\hline Hartz $71-26$ & 49 & 111 & 59 & 81 & 54 & 96 \\
\hline Terra Vig 708 & 59 & 121 & 55 & 93 & 57 & 107 \\
\hline Bragg & 53 & 147 & 53 & 111 & 53 & 129 \\
\hline \multicolumn{7}{|l|}{ Maturity Group VIII } \\
\hline Coker 368 & 52 & 125 & 55 & 86 & 53 & 106 \\
\hline Mean & 48 & 117 & 52 & 86 & 50 & 101 \\
\hline \multicolumn{2}{|c|}{$\begin{array}{l}\text { LSD }(.05) \text { for comparing the } \\
\text { same cultivar between limed } \\
\text { and low-pH treatments within } \\
\text { the same year }\end{array}$} & 13.6 & & & & \\
\hline \multicolumn{2}{|c|}{$\begin{array}{l}\text { LSD }\left({ }_{05}\right) \text { for comparing diff- } \\
\text { erent cultivar means within a } \\
\text { limed or low-pH treatment } \\
\text { within the same year }\end{array}$} & 12.9 & & & & \\
\hline
\end{tabular}

Analysis of seed yield between cultivars on the low $\mathrm{pH}$ soil indicates Ring Around 680, Centennial, and Coker 368 would be expected to have good yields on acid soils. These three cultivars had significantly higher yields on acid soil compared to any other cultivar and demonstrated 30-35 bushels A${ }^{1}$ yields which compared to any other cultivar and demonstrated $30-35$ bushels $\mathrm{A}^{-1}$ yields which compare favorably with the average statewide soybean yield (usually 24 bushels $\mathrm{A}^{-1}$ ). In order to avoid seed yield losses on soils having $\mathrm{pH}$ less than 5.5, these cultivars should be grown or the soil limed to $\mathrm{pH} 5.5$ or higher.

Plant Height, Height to Low Pod, Lodging, and Maturity Date Responses to Liming. Acid soil had a significant effect on plant height (Table 5 ). Since year $x$ lime and year $x$ lime $x$ cultivar effects were insignificant, plant 
Table 5.-Anovar for seed yield and other agronomic characteristics on limed and low-pH soil at Baton Rouge, LA, 1984, 1985, and 1986

\begin{tabular}{|c|c|c|c|c|c|c|c|c|c|c|c|}
\hline \multirow[b]{2}{*}{ Source of Variation } & \multirow[b]{2}{*}{ DF } & \multicolumn{2}{|c|}{ Seed yield } & \multicolumn{2}{|c|}{ Plant height } & \multicolumn{2}{|c|}{ Height to low pod } & \multicolumn{2}{|c|}{ Lodging } & \multicolumn{2}{|c|}{ Maturity Date } \\
\hline & & $\begin{array}{l}\text { Mean } \\
\text { square }\end{array}$ & $\begin{array}{l}\text { Signifi- } \\
\text { cance } \\
\text { level }\end{array}$ & $\begin{array}{l}\text { Mean } \\
\text { square }\end{array}$ & $\begin{array}{l}\text { Signifi- } \\
\text { cance } \\
\text { level }\end{array}$ & $\begin{array}{l}\text { Mean } \\
\text { square }\end{array}$ & $\begin{array}{l}\text { Signifi- } \\
\text { cance } \\
\text { level }\end{array}$ & $\begin{array}{l}\text { Mean } \\
\text { square }\end{array}$ & $\begin{array}{l}\text { Signifi- } \\
\text { cance } \\
\text { level }\end{array}$ & $\begin{array}{l}\text { Mean } \\
\text { square }\end{array}$ & $\begin{array}{l}\text { Signifi- } \\
\text { cance } \\
\text { level }\end{array}$ \\
\hline Year & 2 & 1,373 & .0002 & 10,824 & .0001 & 917 & .0001 & .80 & .06 & 45,904 & .0001 \\
\hline Lime & 1 & 5,074 & .0005 & 2,773 & .005 & 37 & .33 & 10.60 & .001 & 20 & .16 \\
\hline Cultivar & 12 & 940 & .0001 & 2338 & .0001 & 136 & .0001 & .70 & .0001 & 948 & .0001 \\
\hline Year $\times$ Lime & 2 & 33 & .836 & 232 & .36 & 70 & .19 & .12 & .55 & 32 & .08 \\
\hline Year $\times$ Cultivar & 24 & 130 & .0001 & 274 & .0001 & 58 & .0001 & .70 & .0001 & 50 & .0001 \\
\hline Lime $\times$ Cultivar & 12 & 95 & .001 & 55 & .36 & 25 & .06 & .19 & .18 & 11 & .15 \\
\hline Year $\times$ Lime $\times$ Cultivar & 12 & 35 & .4 & 42 & .69 & 27 & .007 & .16 & .32 & 5 & .82 \\
\hline Error (a) & 6 & 35 & & 124 & & 14.3 & & .09 & & 36.3 & \\
\hline Error (b) & 9 & 168 & & 204 & & 34.2 & & .30 & & 7.5 & \\
\hline Error (c) & 215 & 33 & & 50 & & 13.9 & & .14 & & 7.3 & \\
\hline CV (\%) & & 20 & & 8.8 & & 26.4 & & 26.0 & & 2.0 & \\
\hline
\end{tabular}


height within all limed and low-pH plots wre averaged. Limed treatments had an average plant height of 33 inches as compared to 30 inches for the low-pH treatments. Thus acid soil did have a slight effect on reducing plant height.

The analysis of vartiance for lodging was similar to that for plant height. Liming effects were significant, but lime interactions with year and cultivar were insignificant. Lodging score in the limed treatments averaged across years and cultivars was 16 versus 1.2 in low-pH soil. This difference was significant at the 0.01 level.

These results indicate that plants were erect in low-pH plots, while in limed plots, most of the plants were leaning slightly. The increased plant height in limed versus low-pH plots resulted in some lodging, but not great enough to affect yield.

Height to lowest pod and maturity date were not effected by liming treatments, and there were no significant interactions of lime with year or cultivar (Table 5). Height to lowest pod was generally high enough to avoid yield losses at harvest time. Maturity dates were generally the same as have

Table 6.- Seed yield of 13 soybean cultivars on limed and low-pH soil averaged over three years, Baton Rouge, LA 1984, 1985, and 1986

\begin{tabular}{|c|c|c|c|}
\hline \multirow[b]{2}{*}{ Cultivar } & \multicolumn{2}{|c|}{ Seed yield (bu $\left.A^{\prime \prime}\right)$} & \multirow{2}{*}{$\begin{array}{l}\% \text { See Yield } \\
\text { decline due } \\
\text { to acidity }\end{array}$} \\
\hline & Limed & Low-pH & \\
\hline \multicolumn{4}{|l|}{ Maturity Group V } \\
\hline Forrest & 26.5 & 21.7 & 18.1 \\
\hline Deltapine 345 & 23.6 & 21.7 & 8.1 \\
\hline Wilstar 550 & 33.5 & 21.3 & 36.4 \\
\hline \multicolumn{4}{|l|}{ Maturity Group VI } \\
\hline Ring Around 680 & 41.2 & 34.0 & 17.5 \\
\hline Lee 74 & 28.5 & 18.3 & 35.8 \\
\hline Centennial & 39.7 & 31.0 & 21.9 \\
\hline Coker 156 & 33.4 & 24.6 & 26.4 \\
\hline Davis & 35.8 & 19.8 & 44.7 \\
\hline Pickett 71 & 37.2 & 26.6 & 28.5 \\
\hline \multicolumn{4}{|l|}{ Maturity Group VII } \\
\hline Hartz $71-26$ & 31.4 & 26.4 & 15.9 \\
\hline Terra Vig 708 & 26.3 & 24.3 & 7.6 \\
\hline Bragg & 19.3 & 9.7 & 49.7 \\
\hline \multicolumn{4}{|l|}{ Maturity Group VIII } \\
\hline Coker 368 & 40.0 & 31.6 & 21.0 \\
\hline Mean & 32.0 & 23.9 & 25.3 \\
\hline \multicolumn{4}{|c|}{ LSD $\left({ }_{.05}\right)$ to compare limed and low $-\mathrm{pH}$ means within the same cultivar $=3.9$} \\
\hline \multicolumn{4}{|c|}{ LSD $\left({ }_{05}\right)$ to compare cultivar means within a limed or low-pH treatment $=3.3$} \\
\hline
\end{tabular}


been reported in variety testing reports published by the Louisiana Agricultural Experiment Station.

Leaf Mineral Concentrations as Affected by Liming Treatments. Analysis of variance of micronutrient leaf concentrations, percent nitrogen content, and nitrogen uptake are shown in Table 7. Macronutrient data (calcium, magnesium, phosphorus, sulfur, and potassium) are not included since leaf concentrations of these elements were adequate throughout the experiment (data not shown). [Aluminum] and [iron] were not affected by lime or interactions of lime with year or cultivar (Table 7). Both [zinc] and [manganese] were significantly increased in acid soils. However, [zinc] in limed plots always remained above the critical level of 20 parts per million reported by Sedberry et al. (1987) and [zinc] in the low-pH plots was not high enough to be toxic (Table 8).

Leaf concentrations of manganese were most affected by soil acidity. A highly significant lime and lime $x$ cultivar interaction on [manganese] in the leaves occurred (Table 7). When averaged across years and cultivars, leaf manganese] was more than twice as high in low-pH as compared to limed plots. Differences varied depending upon cultivar. Coker 156 had the least increase in [manganese] in low-pH versus limed plots and Bragg had the greatest (Table 8).

Reports from the literature disagree on the level at which manganese becomes toxic. Therefore, it is difficult to state that the manganese concentrations in Table 8 for the low-pH plots were toxic to the cultivars and adversely affected yield. Correlation analysis revealed that [manganese] was negatively correlated with soil $\mathrm{pH}(\mathrm{r}=-0.72, \mathrm{P}=0.001)$, indicating that the high leaf [manganese] was probably caused by high soil manganese concentration which in turn was induced by low soil $\mathrm{pH}$.

Correlation between seed yield and leaf [manganese] was significant ( $\mathrm{r}$ $=-0.33, P=0.001$ ), but did not account for a large amount of the yield variation in the study $\left(\mathrm{r}^{2}=-0.11\right)$. Thus it does not appear that the large yield reductions on low-pH versus limed soil was caused by high leaf [manganese]. These results disagree with other research which reported that aluminum and manganese toxicity were the first and second most important factors, respectively, in causing yield losses on acid soil (Mengel, et al., 1987).

Both percent nitrogen content and nitrogen uptake were significantly affected by lime and the interaction of lime with cultivar (Table 7). Low $\mathrm{pH}$ soil resulted in an average 20 percent decline in percent nitrogen content and 37 percent decline in nitrogen uptake in low-pH versus limed soil. Cultivar yield reductions to acid soil appeared to parallel nitrogen uptake. The four cultivars in which nitrogen uptake was least affected by soil acidityDeltapine 345, Ring Around 680, Hartz 71-26, and Terra Vig 708 (Table 9)were all classified as very insensitive or moderately insensitive in yield reduction due to low $\mathrm{pH}$ soil. Cultivars with the greatest reduction of nitrogen uptake (more than 40 percent) due to low-pH soil-Lee 74, Coker 156, Davis, 
Table 7.-Anovar of leaf concentrations of $\mathrm{Al}, \mathrm{Fe}, \mathrm{Mn}$, and $\mathrm{Zn}$ and whole plant $\mathrm{N}$ percent and uptake at Baton Rouge, LA, 1984

\begin{tabular}{|c|c|c|c|c|c|c|c|c|c|c|c|c|c|}
\hline \multirow[b]{2}{*}{ Source of Variation } & \multirow[b]{2}{*}{ DF } & \multicolumn{2}{|c|}{ Al } & \multicolumn{2}{|c|}{$\mathrm{Fe}$} & \multicolumn{2}{|c|}{$\mathrm{Mn}$} & \multicolumn{2}{|c|}{$\mathrm{Zn}$} & \multicolumn{2}{|c|}{$\% \mathrm{~N}$} & \multicolumn{2}{|c|}{ N Uptake } \\
\hline & & $\begin{array}{l}\text { Mean } \\
\text { square }\end{array}$ & $\begin{array}{l}\text { Signifi- } \\
\text { cance } \\
\text { level }\end{array}$ & $\begin{array}{l}\text { Mean } \\
\text { square }\end{array}$ & $\begin{array}{l}\text { Signifi- } \\
\text { cance } \\
\text { level }\end{array}$ & $\begin{array}{l}\text { Mean } \\
\text { square }\end{array}$ & $\begin{array}{l}\text { Signifi- } \\
\text { cance } \\
\text { level }\end{array}$ & $\begin{array}{l}\text { Mean } \\
\text { square }\end{array}$ & $\begin{array}{l}\text { Signifi- } \\
\text { cance } \\
\text { level }\end{array}$ & $\begin{array}{l}\text { Mean } \\
\text { square }\end{array}$ & $\begin{array}{l}\text { Signifi- } \\
\text { cance } \\
\text { level }\end{array}$ & $\begin{array}{l}\text { Mean } \\
\text { square }\end{array}$ & $\begin{array}{l}\text { Signifi- } \\
\text { cance } \\
\text { level }\end{array}$ \\
\hline Year & 2 & 33,395 & .0003 & 8,018 & .54 & 24,586 & .16 & 2,104 & .001 & .52 & .12 & 2,129 & .0005 \\
\hline Lime & 1 & 677 & .34 & 1,239 & .54 & $1,054,346$ & .0001 & 15,077 & .0001 & 19.89 & .0001 & 4,798 & .0001 \\
\hline Cultivar & 12 & 1,120 & .01 & 7,868 & .03 & 21,897 & .0001 & 555 & .0001 & .91 & .0001 & 160 & .0001 \\
\hline Year $x$ Lime & 2 & 948 & .29 & 1,616 & .61 & 63,051 & .08 & 270 & .40 & .19 & .69 & 170 & .15 \\
\hline Year $\times$ Cultivar & 24 & 924 & .01 & 3,186 & .74 & 1,233 & .99 & 89 & .0009 & .12 & .008 & 51 & .0003 \\
\hline Lime $\times$ Cultivar & 12 & 315 & .82 & 1,071 & .99 & 14,226 & .0001 & 168 & .0001 & .19 & .0009 & 45 & .01 \\
\hline Year $x$ Lime $x$ Cultivar & 12 & 328 & .89 & 4,322 & .37 & 2,214 & .78 & 66 & .02 & .06 & .51 & 20 & .53 \\
\hline Error (a) & 6 & 797 & & 11,880 & & 9,764 & & 94 & & .1948 & & 64 & \\
\hline Error (b) & 9 & 685 & & 3,125 & & 19,166 & & 268 & & .482 & & 73 & \\
\hline Error (c) & 215 & 499 & & 4,002 & & 2,792 & & 39 & & .063 & & 21 & \\
\hline CV (\%) & & 68.9 & & 62.5 & & 32.9 & & 15.6 & & 11.2 & & 26.6 & \\
\hline
\end{tabular}


Table 8.- Mn and $\mathrm{Zn}$ concentrations of soybean leaves as affected by limed and low-pH soil at Baton Rouge, LA, 1984-86

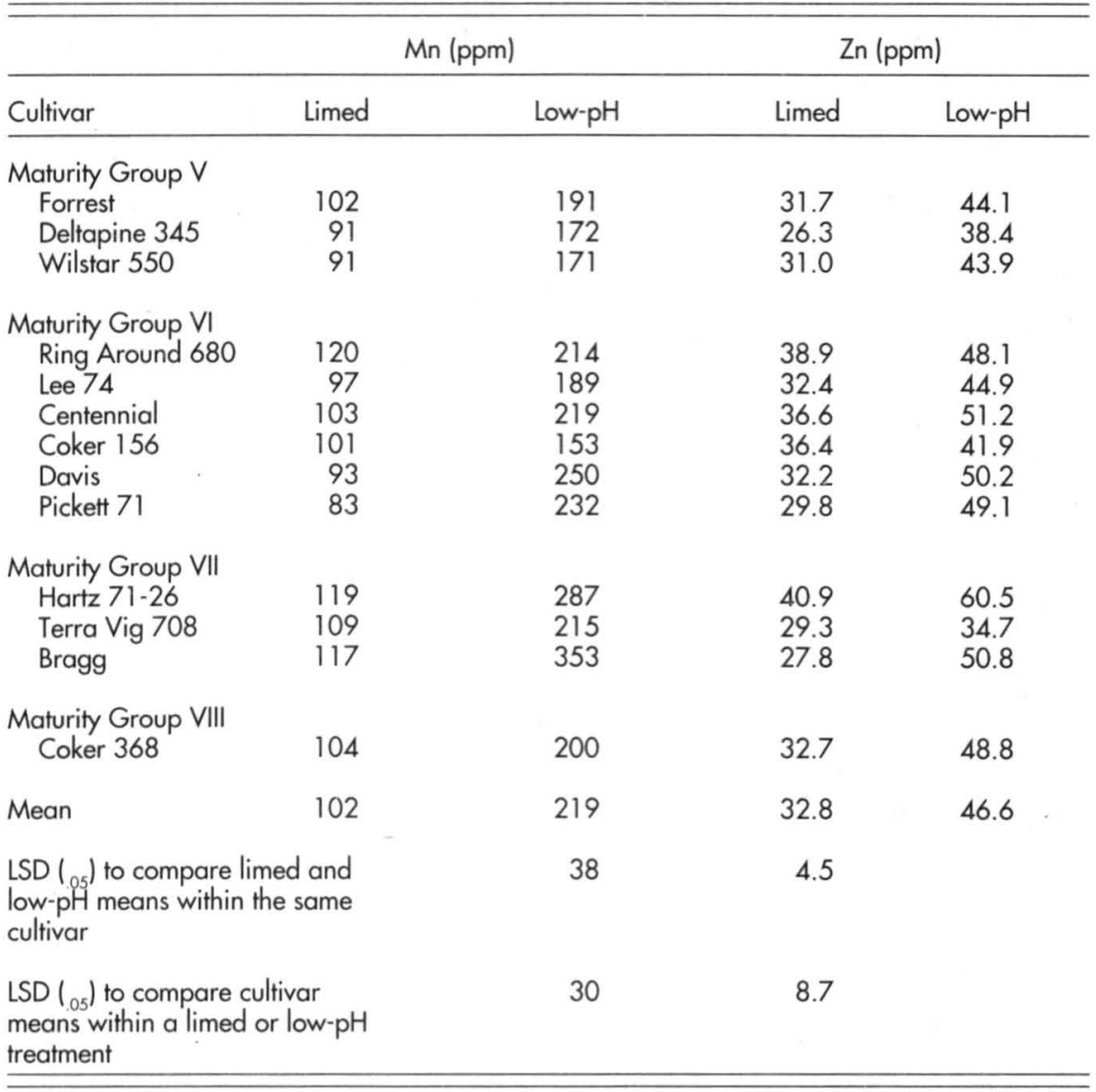

and Bragg-were classified as sensitive to severely sensitive in yield response to low-pH soil.

Correlation analysis involving all observations in the study revealed a close association between yield and nitrogen uptake $(\mathrm{r}=0.49, \mathrm{P}=0.001)$. This correlation is much larger than that between yield and leaf [manganese]. An $\mathrm{r}$ value of $0.83(\mathrm{P}=0.001)$ was shown between percent yield decline and percent decreased nitrogen uptake in low-pH versus limed soil (cultivars averaged across years). This indicates that cultivars having large reductions in nitrogen uptake due to soil acidity also had large yield reductions.

These data suggest that low soil $\mathrm{pH}$ reduced yield primarily through decreasing the plant's ability to fix $\mathrm{N}_{2}$ gas into nitrogen. Low $\mathrm{pH}$ soil impairs this process by interfering with nodulation and / or reducing the availability of molybdenum (Mengel and Kamprath, 1978; Sedberry et al, 1973). Since soil [molybdenum] and nodulation were not measured, it is not possible to determine if these or other factors were responsible. 
Table 9.- Nitrogen content as a percentage of total plant dry weight and nitrogen uptake at $\mathrm{R} 6$ as affected by limed and low-pH soil at Baton Rouge, LA, 1984-86

\begin{tabular}{|c|c|c|c|c|c|}
\hline \multirow[b]{2}{*}{ Cultivar } & \multicolumn{2}{|c|}{ Seed yield (bu $A^{-1}$ ) } & \multicolumn{2}{|c|}{ N uptake (lb $A^{-1)}$} & \multirow{2}{*}{$\begin{array}{l}\text { Percent } \\
\text { decreased } \\
\mathrm{N} \text { uptake } \\
\text { in low-pH } \\
\text { vs limed \% }\end{array}$} \\
\hline & Limed & Low-pH & Limed & Low-pH & \\
\hline $\begin{array}{l}\text { Maturity Group V } \\
\text { Forrest } \\
\text { Deltapine } 345 \\
\text { Wilstar } 550\end{array}$ & $\begin{array}{l}2.61 \\
2.59 \\
2.80\end{array}$ & $\begin{array}{l}2.07 \\
2.38 \\
2.28\end{array}$ & $\begin{array}{l}189.6 \\
166.4 \\
161.1\end{array}$ & $\begin{array}{l}114.8 \\
135.3 \\
100.6\end{array}$ & $\begin{array}{l}39.4 \\
18.7 \\
37.6\end{array}$ \\
\hline $\begin{array}{l}\text { Maturity Group VI } \\
\text { Ring Around } 680 \\
\text { Lee } 74 \\
\text { Centennial } \\
\text { Coker } 156 \\
\text { Davis } \\
\text { Pickett } 71\end{array}$ & $\begin{array}{l}2.51 \\
2.45 \\
2.52 \\
2.52 \\
2.62 \\
2.50\end{array}$ & $\begin{array}{l}2.03 \\
1.88 \\
1.90 \\
1.99 \\
2.12 \\
1.94\end{array}$ & $\begin{array}{l}191.4 \\
173.6 \\
228.3 \\
181.6 \\
182.5 \\
218.9\end{array}$ & $\begin{array}{r}151.3 \\
90.8 \\
142.4 \\
104.1 \\
108.6 \\
135.3\end{array}$ & $\begin{array}{l}20.9 \\
47.7 \\
37.7 \\
42.6 \\
40.5 \\
38.2\end{array}$ \\
\hline $\begin{array}{l}\text { Maturity Group VII } \\
\text { Hartz } 71-26 \\
\text { Terra Vig } 708 \\
\text { Bragg }\end{array}$ & $\begin{array}{l}2.53 \\
2.37 \\
2.19\end{array}$ & $\begin{array}{l}1.91 \\
2.27 \\
1.40\end{array}$ & $\begin{array}{l}194.9 \\
159.3 \\
166.4\end{array}$ & $\begin{array}{r}139.7 \\
121.9 \\
41.8\end{array}$ & $\begin{array}{l}28.3 \\
23.5 \\
74.9\end{array}$ \\
\hline $\begin{array}{l}\text { Maturity Group VIII } \\
\text { Coker } 368\end{array}$ & 2.22 & 1.76 & 212.7 & 135.3 & 36.4 \\
\hline Mean & 2.49 & 1.99 & 186.9 & 117.5 & 37.1 \\
\hline $\begin{array}{l}\text { LSD }\left({ }_{05}\right) \text { to compare } \\
\text { limed and low-pH means } \\
\text { within the same } \\
\text { cultivar }\end{array}$ & .19 & & 25.8 & & \\
\hline $\begin{array}{l}\operatorname{LSD}\left({ }_{05}\right) \text { to compare } \\
\text { cultivar means within } \\
\text { a limed or low-pH } \\
\text { treatment }\end{array}$ & .14 & & 23.1 & & \\
\hline
\end{tabular}

\section{Summary}

The purposes of this study were to identify soybean cultivars which resisted yield reductions on acid soil, to identify cultivars which produce good yields on low-pH soil, and to determine how changes in nutrients affected yields in low-pH soil.

A significant cultivar $\mathrm{x}$ lime interaction indicated that yield in some cultivars was more adversely affected than in others. Terra Vig 708 and Deltapine 345 showed no significant yield loss when grown on low-pH as compared to limed soil, and were classified as very insensitive to soil acidity. Forrest, Ring Around 680, and Hartz 71-26 showed yield losses of only 1618 percent, and were classified as moderately insensitive. 
Cultivars demonstrating 21-29 percent reductions in yield on low-pH versus limed soil were considered to be sensitive to soil acidity. This group included Coker 368, Pickett 71, Coker 156, and Centennial. Lee 74 and Wilstar 550 were more severely affected, and were classified as very sensitive. The cultivars most adversely affected by soil acidity in the study were Davis and Bragg which were judged as severely sensitive. Ring Around 680, Centennial, and Coker 368 gave the highest yields on low-pH soil.

Analysis of variance and correlation studies indicated that the most probable reason for reduced seed yield on acid as compared to limed soil in this study was interference with nitrogen fixation and reduced nitrogen uptake by the plants grown on low $\mathrm{pH}$ soil. 


\section{References}

Adams, F. 1984. Crop response to lime in the Southern United States. In Soil Acidity and Liming (2nd ed). Ed F. Adams. pp 211-265. American Society of Agronomy, Madison, WI, USA.

Anderson, O. E., and J. J. Mortvedt. 1982. Soybeans: Diagnosis and Correction of Manganese and Molybdenum Problems. Southern cooperative series bulletin 281, Univ. of Georgia Col. of Agric. Exp. Stn., Athens, GA, USA, 98 p.

Barnhisel, R., and P. M. Bertsch. 1982. Aluminum. In Methods of Soil Analysis, Agronomy 9, Part 2 (2nd ed). Ed R. C. Dinauer. pp 275-300. American Society of Agronomy, Madison, WI, USA.

Blair, A. W., and A. L. Price. 1923. Studies in toxic properties of soils. Soil Sci. 15, 109-129.

Burnside, D. S. Jr., and M. B. Sturgis. 1958. Soil phosphorus and its fractions as related to response of sugar cane to fertilizer phosphorus. Louisiana Agric. Exp. Stn. Bull. 513.

Caldwell, A. G., E. J. Kamprath, and K. M. Oates. 1984. Response of three soybean cultivars to $\mathrm{pH}$, exchangeable aluminum and extractable manganese. Agron. Abstr. 76,200.

Carter, O. G., I. A. Rose, and P. F. Reading. 1975. Variation in susceptibility to manganese toxicity in 30 soybean genotypes. Crop Sci. 15,730-732.

Cherney, J. H., and D. L. Robinson. 1983. A comparison of plant digestion methods for identifying soil contamination of plant tissues by $\mathrm{Ti}$ analysis. Agron. J. 75, 145-147.

Doolas, G. G. 1930. Soil acidity and soybean inoculation. Soil Sci. 30,275288.

Evans, C. E., and E. J. Kamprath. 1970. Lime response as related to percent aluminum saturation, soil sorbtion aluminum and organic matter content. Soil Sci. Soc. Am. Proc. 34,893-896.

Fehr, W. R., and C. E. Caviness. 1977. Stages of soybean development. Special report 80, Iowa State Univ., Coop. Ext. Serv., Ames, IA.

Foy, C. D. 1974. Effects of aluminum on plant growth. In The Plant Root and Its Environment. Ed E. W. Carson. pp 601-642. University Press of Virginia, Charlottesville, VA, USA.

Foy, C. D. 1984. Physiological effects of hydrogen, aluminum and manganese toxicities in acid soil. In Soil Acidity and Liming (2nd ed). Ed F. Adams. pp 57-97. American Society of Agronomy, Madison, WI, USA.

Havlin, J. L., and P. N. Soltanpour. 1981. A nitric acid plant tissue digest method for use with inductively coupled plasma spectrometer. Agron. Abstr. 73, 178. 
Heenan, D. P., and O. G. Carter. 1976. Tolerance of soybean cultivars of manganese toxicity. Crop Sci. 16,389-391.

Helyar, K. R. 1978. Effects of aluminum and manganese toxicity on legume growth. p. 207-231. In Mineral Nutrition of Legumes in Tropical and Subtropical Soils. Eds G. S. Andrew and E. J. Kamprath. pp 207-231. Commonwealth Scientific and Industrial Research Organization (CSIRO), Melbourne, Australia.

Lindsay, W. L., and W. A. Norvell. 1978. Development of a DTPA test for zinc, iron, manganese, and copper. Soil Sci. Soc. Am. J. 42,421-428.

Lucas, R. E., and B. D. Knezek. 1971. Climatic and soil conditions promoting micronutrient deficiencies in plants. In Micronutrients in Agriculture. Eds J. J. Mortvedt et al. pp 265-288. Soil Science Society of America, Madison, WI, USA.

McLean, E. O. 1982. Soil pH and lime requirement. In Methods of Soil Analysis, Agronomy no. 9, part 2 (2nd ed.). Ed R. C. Dinauer. pp 199224. American Society of Agronomy, Madison, WI, USA.

McLean, F. T., and B. E. Gilbert. 1927. The relative aluminum tolerance of crop plants. Soil Sci. 24,163-174.

McLean, F. T., and B. E. Gilbert. 1928. Aluminum toxicity. Plant Physiol. 3,293-302.

Mengel, D. B., and E. J. Kamprath. 1978. Effect of soil pH and liming on growth and nodulation of soybeans on Histosols. Agron. J. 70,959-963.

Mengel, D. B., W. Segars, and G. W. Rehm. 1987. Soil fertility and liming. 461-489. In Soybeans: Improvement, Production, and Uses (2nd ed.). Ed J. R. Wilcox.pp 461-489. American Society of Agronomy, Madison, WI, USA.

Ohki, K. 1976. Manganese deficiency and toxicity levels for "Bragg" soybeans. Agron. J. 68,861-864.

Ohki, K., D. O. Wilson, and O. E. Anderson. 1988. Manganese deficiency and toxicity sensitivities of soybean cultivars. Agron. J. 72,713-716.

Sartain, J. B. 1974. Differential Effects of Aluminum on Top and Root Growth, Nutrient Accumulation and Nodulation of Several Soybean Varieties. Ph.D. diss. North Carolina State Univ., Raleigh, NC, USA (Diss. Abstr. 358,641).

Sedberry, J. E. Jr., T. S. Dharmaputra, R. H. Brupbacker, S. A. Phillips, J. G. Marshall, L. W. Sloane, D. R. Melville, J. L. Rabb, and L. H. Davis. 1973. Molybdenum investigations with soybeans in Louisiana. Louisiana Agr. Exp. Stn. Bull. 670. 
Sedberry, J. E. Jr., M. C. Amacher, D. P. Bligh, and O. D. Curtis. 1987. Plant tissue analysis as a diagnostic aid in crop production. Louisiana Agric. Expt. Stn. Bull. 783.

Thomas, G. W. 1982. Exchangeable cations. In Methods of Soil Analysis, Agronomy no. 9, part 2 (2nd ed). Ed R. C. Dinauer. pp 159-165. American Society of Agronomy, Madison, WI, USA. 

Louisiana Agricultural Experiment Station LSU Agricultural Center

Drawer E

Baton Rouge, LA. 70893-0905

Non-profit Org. U.S. Postage

PAID

Permit No. 733

Baton Rouge, LA 